\title{
Information-Seeking Behavior of International Graduate Students vs. American Graduate Students: A User Study at Virginia Tech 2005
}

\author{
Yan Liao, Mary Finn, and Jun Lu
}

\begin{abstract}
This is a comparative study on information needs and information-seeking behavior of international graduate students and American graduate students. This user study is based on empirical data collected from an online survey conducted between April 7 and May 28, 2005, at Virginia Tech. The goal of this comparative study is to investigate how graduate students from diverse ethnic groups discover, select, and use various information sources and to obtain insights into international graduate students' information-seeking behavior, especially its similarities and differences compared with the information-locating patterns used by their American peers.
\end{abstract}

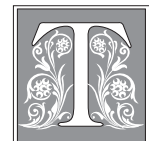

he international student population in United States colleges and universities is continuously increasing. Since 1984 the United States has ranked first worldwide in the number of international students. In 2000, of the 1.2 million students pursuing postsecondary education outside their home countries, more than one third choose to study in the United States. Even after the events of September 11, 2001, the United States is still the first choice for study abroad for many international students, especially at the graduate level. ${ }^{1}$ Although preceded by five years of steady growth, the number of international students enrolled in U.S. higher education institutions did decrease by 2.4 percent in 2003-2004 to a total of 572,509, according to Open Doors 2004. There has also been an increase of 2.5 percent in the total number of graduate enrollments with wide diversity among graduate fields and institutions, which partially offset a 5 percent decline in the number of international undergraduate students. ${ }^{2}$

At Virginia Tech, international graduate students accounted for 25 percent

Yan Liao served as Cataloging Librarian at Virginia Polytechnic Institute and State University Library and currently works at Georgetown University Law Library as Head of Cataloging; e-mail: yl233@law. georgetown.edu. Mary Finn is Head of Expedited Cataloging at Virginia Polytechnic Institute and State University Library and Jun Lu is Assistant Professor of the Department of Mathematics and Statistics at American University; e-mail: maryfinn@vt.edu, and lu@american.edu, respectively. This research was funded by a grant from the Virginia Tech University Libraries Travel and Research Committee. The authors wish to acknowledge assistance from graduate school officials: Monika Gibson, Ruth Athanson, and Sherri Turner; and to express appreciation to the following Virginia Tech librarians: Paul Metz, Althea Aschmann, Margaret Merrill, Dave Beagle, Vicki Kok, Bruce Obenhaus, Michelle Young, Luke Vilelle; and Professor of Information Science at University of Missouri, Columbia: John Budd. 
(1465) of the total graduate program enrollment in spring semester 2005. ${ }^{3}$ These students form a unique multicultural user group for the university libraries. Majoring in a variety of disciplines, many international graduate students are working as teaching or research assistants in different departments. Understanding and meeting their affective as well as cognitive needs will not only help them achieve higher level of academic success but also enhance universities' teaching and research capabilities.

There is a vast research literature exploring topics on academic library services and multicultural communities. These works on academic multicultural environments can be divided into two categories. The first generally examines the roles of academic libraries and their responses to multiculturalism. Most of the articles in this category discuss services to students. ${ }^{4}$ The other category, with relatively fewer articles, focuses upon the international group itself, studying the information needs and information-seeking behavior of multicultural students. The literature review revealed a gap in studies of the international group over the past decade. Many of the earlier studies were done in the mid 1990s or even earlier. (Louise W. Greenfield 1988; ${ }^{5}$ Kwasi Sarkodie-Mensah 1986, ${ }^{6} 1992,{ }^{7}$ Mary Beth Allen 1993-survey conducted in 1988; Suzanne Irving 1994; ${ }^{9}$ Nancy Moeckel and Jenny Presnell 1995-survey conducted in 1991; $;{ }^{10}$ Menxiong Liu and Bernice Redfern 1997-survey conducted $1995 .{ }^{11}$ )

Most of the 1990s studies identify two distinct barriers that affect the success level of the use of libraries by international students.

One is language/culture barrier, which impedes communication between users and librarians. It was estimated that the average international student has only 50 percent of the reading speed and comprehension of his or her American counterpart, and oral comprehension is less than 50 percent. $^{12}$ Many international students were observed pronouncing English words in a nonstandard way. ${ }^{13}$ A lack of fluency in English may result in failed online catalog searching. ${ }^{14}$ International students with English as their primary language were more successful in using the library than those for whom English is not their native language.${ }^{15}$ Several cultural attributes were found in international student groups that also create barriers to library access, including different cultural body language and gestures, social class and religious differences, traditional passive roles of learners, and shyness about approaching authority figures for assistance. ${ }^{16}$

Narrow concepts of the nature of library services and functions formed in their own countries created another barrier for international students. Many foreign libraries did not have the benefit of open stacks and trained librarians. ${ }^{17}$ Traditional research tools were not always available or well organized..$^{18}$ In some developing countries, academic libraries were treated simply as study halls and students had never learned to expect service and freedom of access in American libraries. In contrast, many American students have a better understanding of library services and functions. ${ }^{19} \mathrm{~A}$ few researchers suggest that some international students were baffled by unfamiliar technologies, ${ }^{20}$ such as CD-ROMs, microfiche, audiovisual equipment, and the OPAC (Online Public Access Catalog). ${ }^{21}$

Ten years later, we have seen significant improvement in both English proficiency and information technology development worldwide, especially in many developing countries. Governments of those countries are paying more attention to the teaching of English in recent years. In Asia, a large source of international students, children are now starting to learn English in early elementary school rather than beginning in junior high school as done in the past. Evidence of the improvement of English proficiency is the increased scores in the TOEFL (Test of English as a Foreign Language), which is required for foreign students pursuing higher education in 
the United States. The test measures the ability of nonnative speakers of English to use and understand North American English as it is spoken, written, and heard in college and university settings. ${ }^{22}$ ETS (Educational Testing Services) TOEFL score data summary reports showed a steady increase of mean scores of graduate-level students (covering all examinees who, on the exam sheet, indicated that they were applying for admissions to colleges or universities as graduate students) during the past 10 years, from 532 (paper-based test, full score 677) in July 1991-June 1993 to 223 (computer-based test, equals 563 in paper-based test) in July 2003-June 2004. ${ }^{23}$ In accordance with the ongoing improvement of the English proficiency level of international students within the past decade, language barriers are less severe than they were previously. At the same time, rapid development of information technology has innovatively changed the academic libraries in developing countries in the past ten years. According to the Fall 2003 International Student Survey at San Jose State University, 94 percent of incoming international students used a library in their home country before coming to the United States. Of those, 84 percent used a computer inside a library. ${ }^{24}$ Digital library access and research are no longer new to many international students. This result reveals a significant difference between international student surveys conducted in the 1980s and early 1990s and the current students. Thus, theoretically, emerging information technology shouldn't be a major obstacle standing between international patrons and the information sources as it appeared to be 10 years ago.

Do the barriers mentioned above continue to hinder international students' success in information searching? Is there an improvement in information-seeking skills of current international students? Can they use academic libraries and other information sources more effectively than before? The authors find current research on international students' library experience and needs lacking in the literature, so there is insufficient data to answer the questions above. Further, this study is unique in that previous research has not been done studying the similarities and differences between international students' information-seeking behavior and that of American students.

This comparative study focuses on graduate student groups. It offers a current view of information needs and information-seeking experiences of the growing international library user base. In addition, this research should help academic librarians understand more about the domestic patron group, and find more effective and cost-efficient systems to serve both groups.

\section{Methodology and Data Collection}

A Web-based anonymous survey was published on Survey Monkey from April 7 to May 28, 2005. With the assistance of the graduate school and departments' graduate program heads, the cover letter and the survey link was sent to graduate students via their listserv. A short announcement had also been posted in the news announcement column at university library's homepage for one and a half months.

The survey questionnaire consisted of four sections. Section I was structured to elicit some demographic information about the study group. Section II sought to investigate the general information about searching patterns. Section III focused on library activities. Section IV is an openended question for final comments.

The authors employed statistical hypothesis testing techniques to study the following three areas:

1. Compare the information needs and information-seeking behavior of international graduate students compared with American graduate students.

2. Investigate the relationship between English language proficiency of international graduate students and their information-seeking behavior. 
3. Investigate the relationship between length of stay in the United States of international graduate students and their information-seeking behavior.

A series of null hypotheses have been tested. A Chi-square test statistic was calculated from a contingency table in each hypothesis test and an ANOVA F test was conducted to all the questions with answers that can be numerically measured: for example, answers "never" to "very often" can be measured from 1 to 5 . Corresponding $p$ values were obtained from both tests. To reduce the risk of inflating the overall rate of false significance, the authors used a small critical value $(\alpha=0.01)$ for all the hypothesis tests. The null hypotheses would be rejected if the resulting $p$ values are less than the critical value $\alpha$. The Chi-square test has been widely used to evaluate the dependence and association of categorical variables, and the ANOVA analysis is used to further evaluate the difference of the group means.

Since this study discusses both similarities and differences of the information-seeking behaviors of the two groups, highest rated choices will be listed in the findings, whether or not there are significant differences in the choices.

\section{Findings}

\section{Section I: Profile of the study group}

According to the Virginia Tech Spring 2005 enrollment profile, there are 5,765 graduate students (3,568 full-time and 2,197 part-time). About 6.3 percent (362) graduate students responded to the survey. Of those surveys returned, 315 were valid. The sample size exceeded the Chisquare test requirements.

Among the 315 respondents, 71.1 percent (224) are American students (U.S. citizen/permanent resident) and 28.9 percent (91) are international students. International respondents came from 27 countries. Their geographic distribution is reported in table 1 . The respondent structure of the survey closely resembles the demographic distribution of graduate students at Virginia Tech, which significantly decreased the risk of skewing or biasing survey data. (See figure 1 and table 1.)

Another demographic factor examined was the total number of years the international students had been studying in the United States. Almost half of the international respondents (49.4\%) indicated that they've been in the United States for 2-5 years; 29.7 percent reported less than 2 years, and 20.9 percent have been in the United States for 5 years or more.

Concerning the English proficiency question, a total of 85 respondents, including 75 international and 10 American students, claimed that English is not their primary language. Table 2 shows their English proficiency in speaking, listening, writing, and reading. Reading, listening, and speaking comprehension are very important during the information-seeking process. The data 


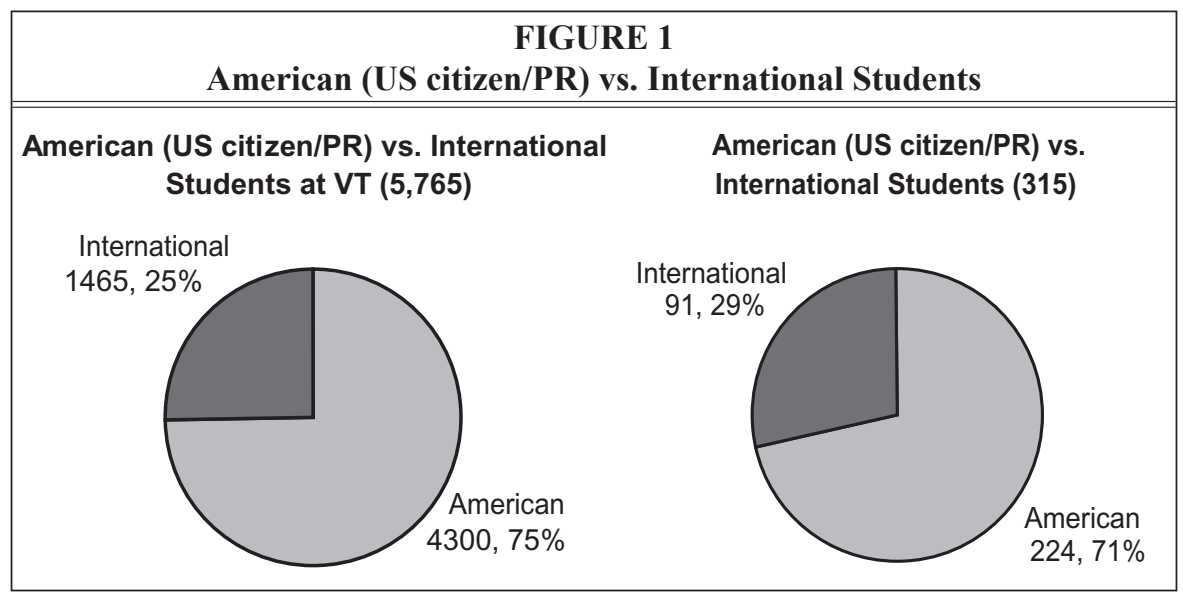

indicates that graduate students, whose primary language isn't English, have strong confidence in their English skills.

\section{Section II: General Information-Seeking Behavior}

The term "Information-Seeking Behavior," although seemingly self-explanatory, actually covers a broad range of potential activities. In this study, the authors briefly break the process into three linear stages:

1. Initiating: how do graduate students begin locating information they want

2. Searching: which methods are most often used by graduate students

3. Locating: where do graduate students usually find the information they want

\section{Stage 1: Initiating}

In "how do you usually START to locate wanted information (check one answer)," the authors listed eight methods in addition to one open-ended choice ("other") in which students could specify other methods not on the list. It was a single-choice question. The purpose was to identify the exact starting point of the information-seeking process for each student.
The null hypothesis being tested is that there is no significant difference of the preferences of starting method between international graduate students and the American graduate students. With Chisquare $=22.285, \mathrm{df}=6, p<0.001(p<\alpha)$, the authors found the preferences of initial information channels are significantly different among international and American respondents. Almost half the international respondents said they initiated searching from the Internet. Their second choice $(16.5 \%)$ is VT E-resources (including electronic journals, databases, and electronic theses and dissertations), while 40.6 percent American respondents tended to search VT E-resources first (see table 3).

\section{Stage 2: Searching}

During the searching process, there are six methods out of nine seeking procedure choices with response frequencies above average (see figure 2).

\section{TABLE 2}

\section{English Proficiency}

\begin{tabular}{|l|c|c|c|c|c|c|}
\hline \hline & \multicolumn{2}{|c|}{ Poor/Fair } & \multicolumn{2}{c|}{ Good } & \multicolumn{2}{c|}{$\begin{array}{c}\text { Very Good/ } \\
\text { Excellent }\end{array}$} \\
\hline & Freq. & $\%$ & Freq. & $\%$ & Freq. & $\%$ \\
\hline Speaking & 22 & $25.9 \%$ & 22 & $25.9 \%$ & 41 & $48.2 \%$ \\
\hline Listening & 16 & $18.8 \%$ & 24 & $28.2 \%$ & 45 & $52.9 \%$ \\
\hline Writing & 21 & $24.7 \%$ & 26 & $30.6 \%$ & 38 & $44.7 \%$ \\
\hline Reading & 9 & $10.6 \%$ & 21 & $24.7 \%$ & 55 & $64.7 \%$ \\
\hline
\end{tabular}




\begin{tabular}{|l|c|r|r|r|r|r|r|r|}
\hline \multicolumn{1}{|c|}{ TABLE 3 } \\
\hline \hline & & $\begin{array}{l}\text { Classmates/ } \\
\text { Professors/ } / \\
\text { Librarians }\end{array}$ & $\begin{array}{r}\text { Reference } \\
\text { Resources }\end{array}$ & $\begin{array}{c}\text { Textbooks/ } \\
\text { Lecture } \\
\text { Notes }\end{array}$ & $\begin{array}{c}\text { Addison } \\
\text { Catalog }\end{array}$ & $\begin{array}{c}\text { VT E- } \\
\text { Resources }\end{array}$ & Internet & Other \\
\hline International & Freq. & 9 & 2 & 7 & 12 & 15 & 45 & 1 \\
\hline & $\%$ & $9.9 \%$ & $2.2 \%$ & $7.7 \%$ & $13.2 \%$ & $16.5 \%$ & $49.5 \%$ & $1.1 \%$ \\
\hline American & Freq. & 22 & 10 & 11 & 20 & 91 & 65 & 5 \\
\hline & $\%$ & $9.8 \%$ & $4.5 \%$ & $4.9 \%$ & $8.9 \%$ & $40.6 \%$ & $29 \%$ & $2.2 \%$ \\
\hline $\begin{array}{l}\text { Chi-square }=22.285, \mathrm{df}=6, p<0.001 \\
(\text { The null hypothesis that there is no significant difference of the preferences of starting method between } \\
\text { international respondents and American respondents is rejected.) }\end{array}$ \\
\hline
\end{tabular}

The statistical analysis didn't find a significant difference among the choices of these methods, except in "Search Addison Catalog." Table 4 shows that international respondents search the library online catalog significantly more often than American respondents.

Figure 2 shows that the Internet is the most frequently used information resource. What Internet tools are most used by graduate students? The authors offered eight answers and one additional openended choice ("other"). Students were allowed to check one or more answers. The study found that top three favorite Web searching tools are "Search Engines," "VT library Web sites," and "Online reference tools." The three least favorite tools are "Web directories," "Online discussion forums," and "Weblog" (see figure 3).

Cross-tabulations were performed to find significant differences of preferences for these tools between the two groups.
The result shows that international and American respondents have similar preferences of the top 3 Internet tools. But significantly more international respondents (11\%) would search "Online discussion forums" than American respondents $(3.1 \%)($ Chi-square $=7.838, \mathrm{df}=1, \mathrm{p}<0.005)$, while more American respondents $(44.6 \%)$ would explore "professional association Web sites" than international respondents (24.2\%) (Chi-square=11.423, $\mathrm{df}=1, \mathrm{p}<0.001)$.

\section{Stage 3: Locating}

For the question "where do you usually find the wanted information," students were able to check more than one answer out of eight choices, and they could also indicate other answers beyond the list. Figure 4 shows that the top three information sources are "VT E-Journals," "Library sponsored E-resources," and "Library books."

\begin{tabular}{|l|l|r|r|r|r|r|r|}
\hline \multicolumn{1}{|c|}{ TABLE 4 } \\
Search Addison Catalog \\
\hline \hline & Never/Seldom (0) & Occasionally (3) & Often/Very Often (5) & Means \\
\hline & Freq. & $\mathbf{\%}$ & Freq. & \multicolumn{1}{|c|}{$\%$} & Freq &.$\%$ & \\
\hline International & 6 & $6.6 \%$ & 10 & $11 \%$ & 75 & $82.4 \%$ & 4.52 \\
\hline American & 28 & $12.5 \%$ & 59 & $26.3 \%$ & 137 & $61.2 \%$ & 3.97 \\
\hline $\begin{array}{l}\text { Chi-square=13.397, df=2, } p<0.001 \\
\text { ANOVA F }=10.626, p<0.001 \\
\text { (The null hypothesis that there is no significant difference of the frequencies of using library online } \\
\text { catalog between international respondents and American respondents is rejected.) }\end{array}$ \\
\hline
\end{tabular}




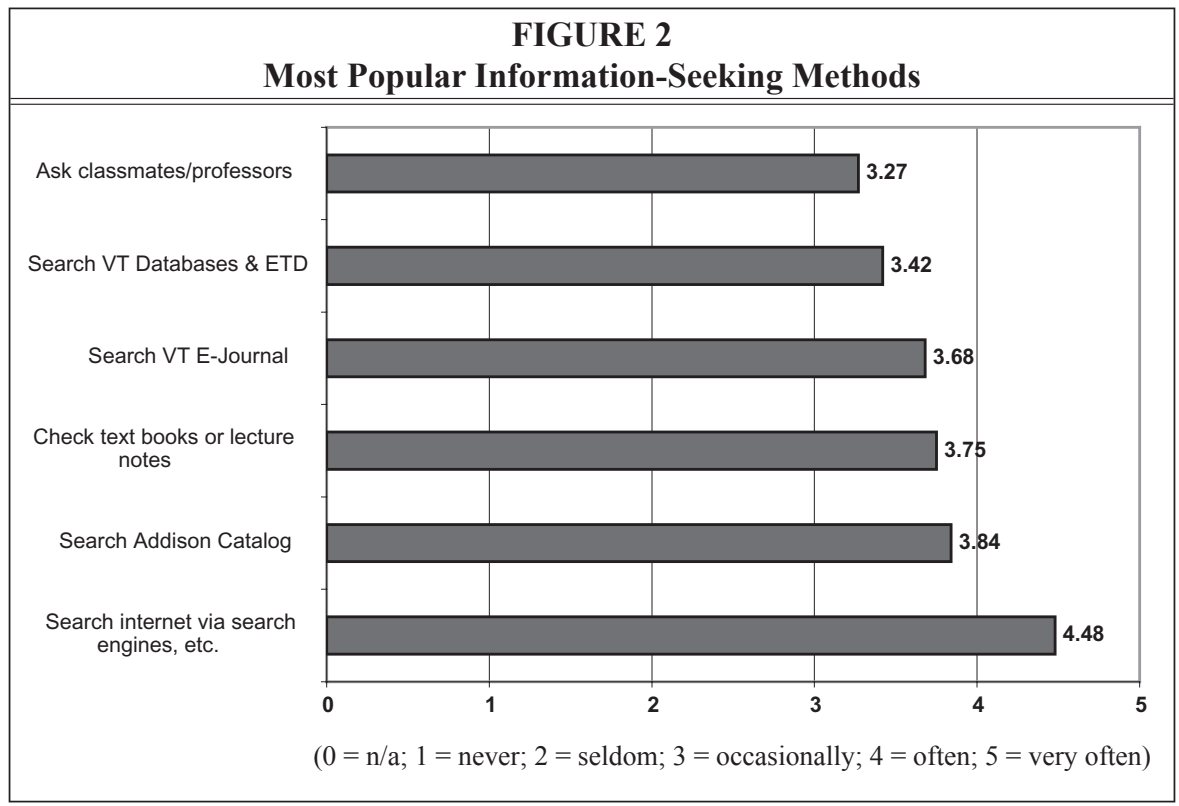

The statistical analysis found only one different preference: 58.2 percent international respondents said that they find the wanted information in library books, while only 38.8 percent American respondents checked this answer (Chisquare=9.866, $\mathrm{df}=1, p<0.002$ ).

Figure 2 demonstrates that compared with print resources, respondents favor electronic formats. This preference is consistent with the result of the follow- ing question: "How do the following factors affect your information resource choices?" The response averages of all six factors are above "3 (somewhat important)" (see figure 5). Respondents treated accessibility as a more important factor than stability. Online resources allow more flexible access. Full-text keyword searching is another great feature that print resources don't have, which can help users to jump to a relevant paragraph

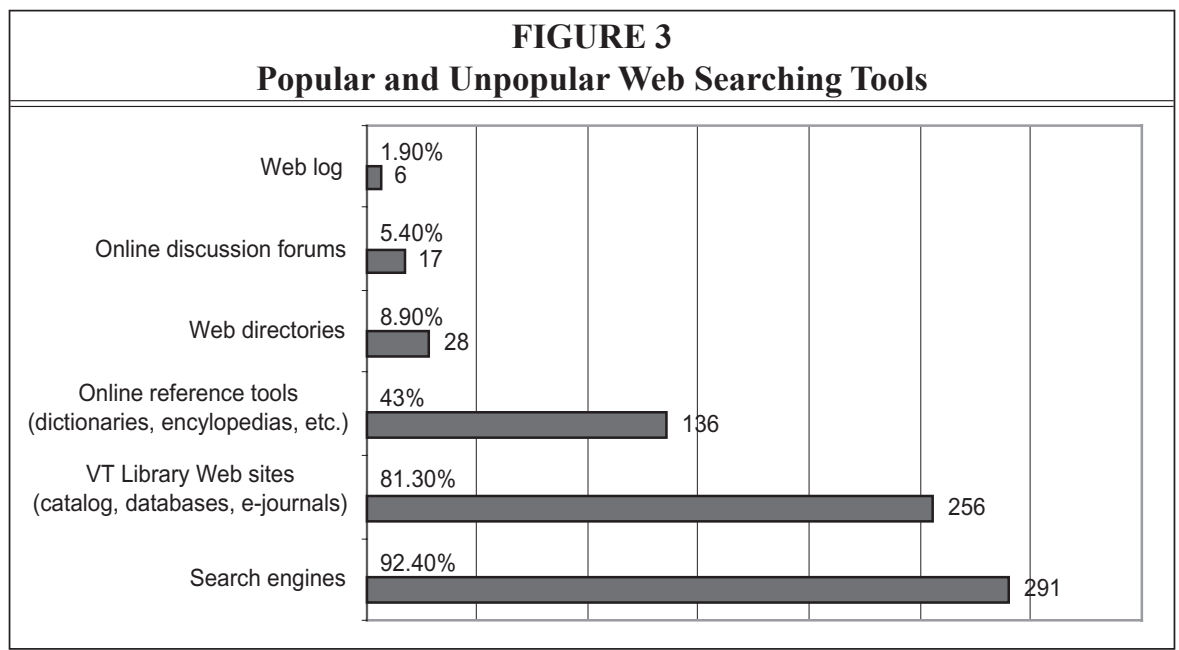




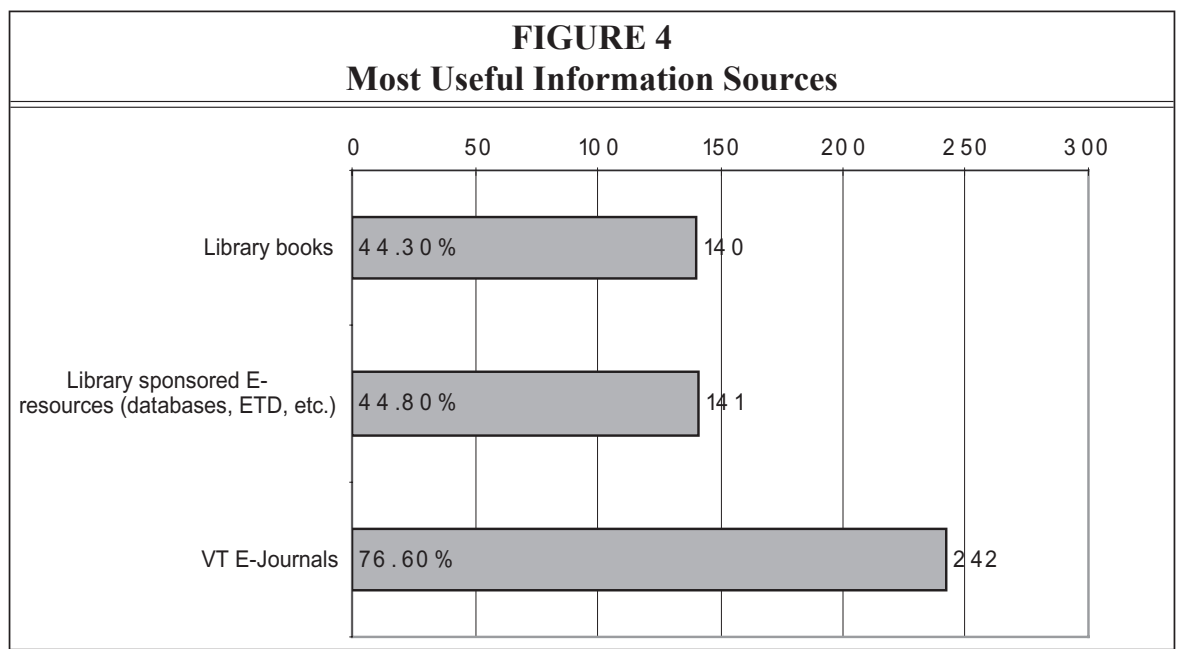

instantly. Although the stability of online resources isn't as good as print resources, graduate students will choose them first in most cases. The statistical analysis shows that these factors have similar influence on international respondents as on American respondents.

\section{Section III: Library Activities Information}

This section focused on the use of library resources. It investigated the following aspects:

\section{Use of library in graduate study vs. in} undergraduate study:

Analyses of the frequency of library use shows that during undergraduate studies, international respondents used libraries as often as American respondents. However, in graduate programs, international students use library services, both in onsite visits and in online searching, more often than their American counterparts (see tables 5 and 6).

Compared with library resources and services in undergraduate studies, how many Virginia Tech library resources/services are new to graduate students? Figure 6 shows that among nine choices, the top three new services are "Reference counseling service via online chat or email" 66 percent (207), “Interlibrary loan" 58 per-

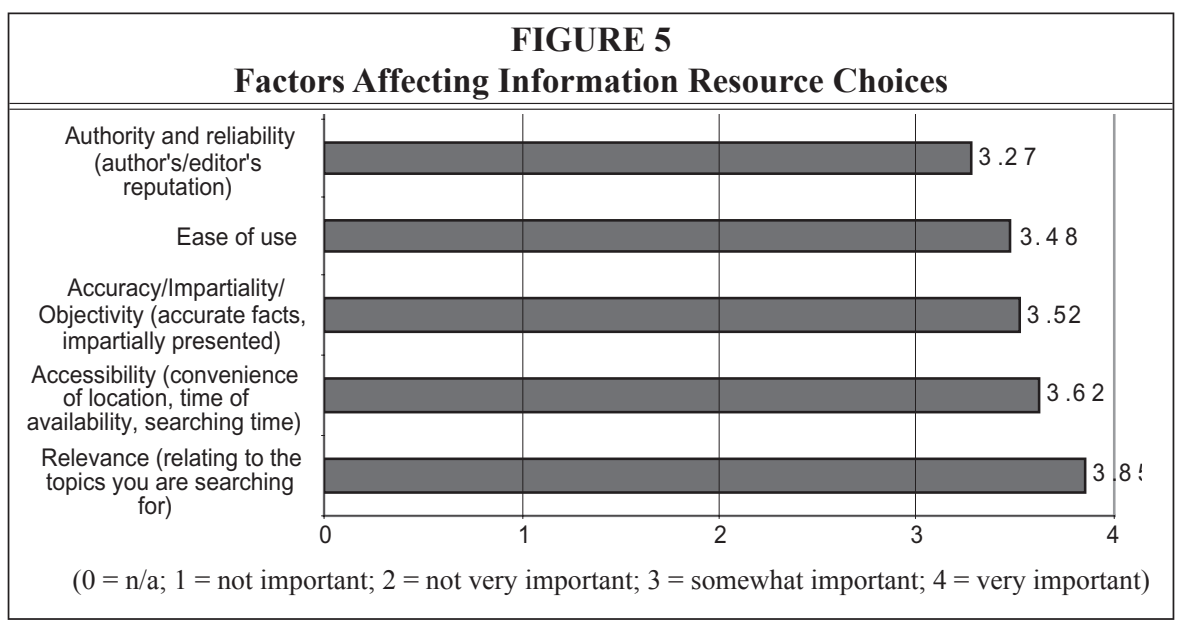




\begin{tabular}{|c|c|c|c|c|c|c|c|}
\hline \multicolumn{8}{|c|}{$\begin{array}{c}\text { TABLE } 5 \\
\text { Visit University Libraries from January through April } 2005\end{array}$} \\
\hline & \multicolumn{2}{|c|}{ Never/Seldom (1) } & \multicolumn{2}{|c|}{ Occasionally (3) } & \multicolumn{2}{|c|}{ Often/Very often (5) } & \multirow[t]{2}{*}{ Means } \\
\hline & Freq. & $\%$ & Freq. & $\%$ & Freq & $\%$ & \\
\hline International & 7 & $7.7 \%$ & 23 & $25.3 \%$ & 61 & $67 \%$ & 4.19 \\
\hline American & 66 & $29.5 \%$ & 73 & $32.6 \%$ & 85 & $37.9 \%$ & 3.17 \\
\hline \multicolumn{8}{|c|}{$\begin{array}{l}\text { Chi-square }=26.184, \mathrm{df}=2, p<0.001 \\
\text { ANOVA } \mathrm{F}=28.266, p<0.001 \\
\text { (The null hypothesis that there is no significant difference in the frequencies of visiting university li- } \\
\text { braries from January through April } 2005 \text { between international respondents and American respondents } \\
\text { is rejected.) }\end{array}$} \\
\hline
\end{tabular}

\begin{tabular}{|c|c|c|c|c|c|c|c|}
\hline \multicolumn{8}{|c|}{$\begin{array}{c}\text { TABLE } 6 \\
\text { Search Library Web Sites from January through April } 2005\end{array}$} \\
\hline & \multicolumn{2}{|c|}{ Never/Seldom (1) } & \multicolumn{2}{|c|}{ Occasionally (3) } & \multicolumn{2}{|c|}{ Often/Very often (5) } & \multirow[t]{2}{*}{ Means } \\
\hline & Freq. & $\%$ & Freq. & $\%$ & Freq & $\%$ & \\
\hline International & 2 & $2.2 \%$ & 15 & 16.5 & 4 & $81.3 \%$ & 4.58 \\
\hline American & 29 & $12.9 \%$ & 51 & $22.8 \%$ & 144 & $64.3 \%$ & 4.03 \\
\hline \multicolumn{8}{|c|}{$\begin{array}{l}\text { Chi-square }=11.529, \mathrm{df}=2, p<0.003 \\
\text { ANOVA } \mathrm{F}=11.755, p<0.001 \\
\text { (The null hypothesis that there is no significant difference in the frequencies of searching library Web } \\
\text { sites from January through April } 2005 \text { between international respondents and American respondents } \\
\text { is rejected.) }\end{array}$} \\
\hline
\end{tabular}

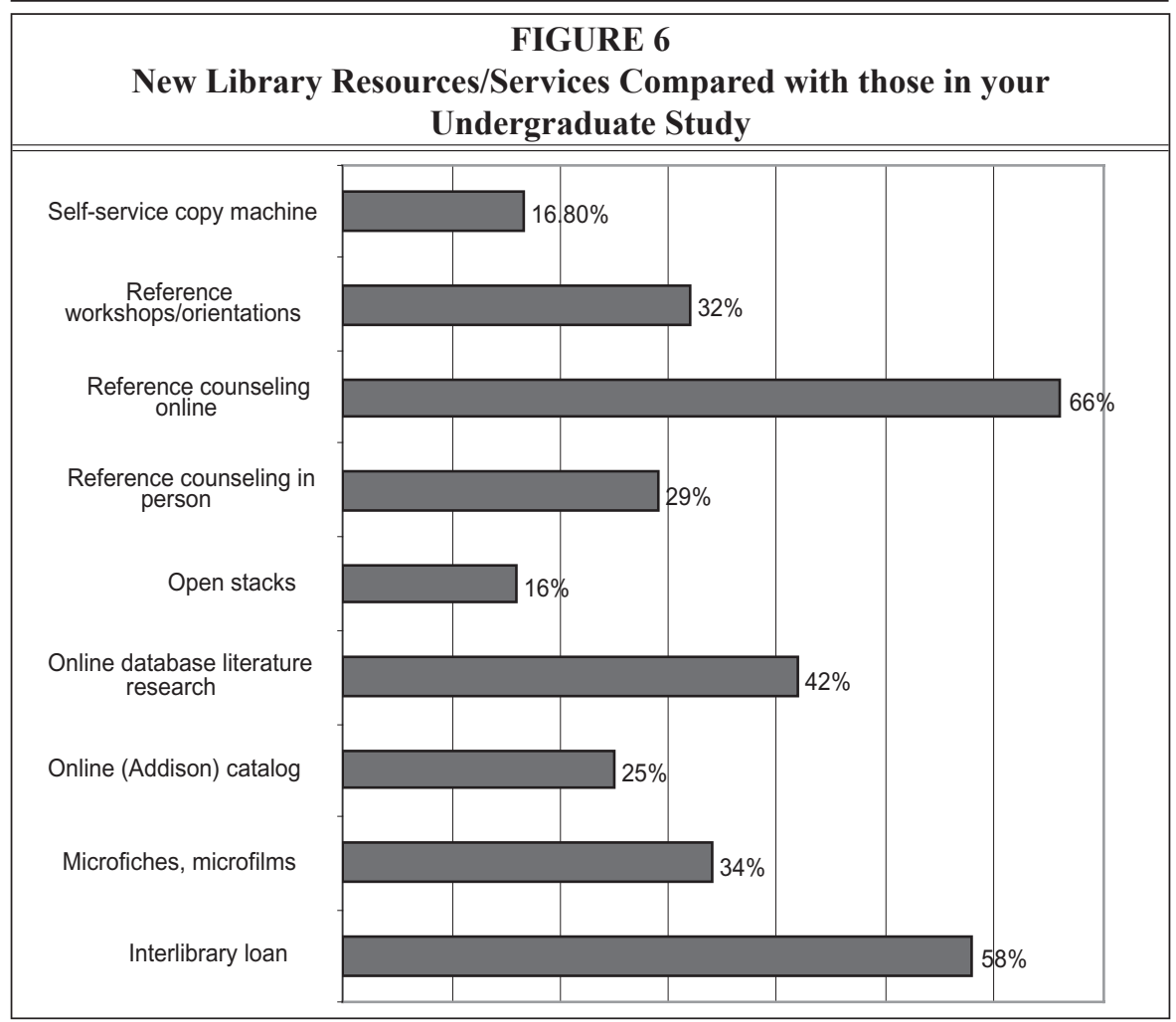




\begin{tabular}{|l|c|c|c|c|}
\hline \multicolumn{5}{|c|}{ TABLE 7 } \\
New Library Services \\
\hline \hline Library Services & $\begin{array}{c}\text { International } \\
\text { (New to me \%) }\end{array}$ & $\begin{array}{c}\text { American } \\
\text { (New to me \%) }\end{array}$ & $\begin{array}{c}\text { Chi- } \\
\text { Square }\end{array}$ & $p$ value \\
\hline Interlibrary loan & $87.9 \%$ & $45.5 \%$ & 47.635 & $p<0.001$ \\
\hline Microfiches, microfilms & $71.4 \%$ & $18.3 \%$ & 81.799 & $p<0.001$ \\
\hline Online (Addison) catalog & $46.2 \%$ & $16.5 \%$ & 30.248 & $p<0.001$ \\
\hline $\begin{array}{l}\text { Online database literature } \\
\text { search }\end{array}$ & $59.3 \%$ & $34.8 \%$ & 15.980 & $p<0.001$ \\
\hline Open stacks & $26.4 \%$ & $12.5 \%$ & 9.037 & $p<0.003$ \\
\hline $\begin{array}{l}\text { Reference counseling } \\
\text { (in person) }\end{array}$ & $40.7 \%$ & $25 \%$ & 7.626 & $p<0.006$ \\
\hline Reference counseling (online) & $76.9 \%$ & $60.7 \%$ & 7.513 & $p<0.006$ \\
\hline Reference workshop/orientation & $52.7 \%$ & $23.7 \%$ & 25.133 & $p<0.001$ \\
\hline Self-service copy machine & $44 \%$ & $5.8 \%$ & 67.308 & $p<0.001$ \\
\hline $\begin{array}{l}\text { (The null hypothesis that all these library services are equally new to international respondents and } \\
\text { American respondents is rejected.) }\end{array}$ & & & \\
\hline
\end{tabular}

TABLE 8

Difficulty Level of Using Library Services/Resources

\begin{tabular}{|l|c|c|c|c|c|c|}
\hline \hline & $\begin{array}{c}\text { Not } \\
\text { Interested } \\
\% \text { (Freq.) }\end{array}$ & $\begin{array}{c}\text { Will Try } \\
\text { Later } \\
\% \text { (Freq.) }\end{array}$ & $\begin{array}{c}\text { Easy } \\
\% \text { (Freq.) }\end{array}$ & $\begin{array}{c}\text { Difficult } \\
\% \text { (Freq.) }\end{array}$ & $\begin{array}{c}\text { Very } \\
\text { Difficult } \\
\% \text { (Freq.) }\end{array}$ & $\begin{array}{c}\text { N/A } \\
\text { (Freq.) }\end{array}$ \\
\hline Interlibrary loan & $11 \%(36)$ & $17 \%(52)$ & $59 \%(188)$ & $6 \%(18)$ & $1 \%(2)$ & $6 \%(19)$ \\
\hline $\begin{array}{l}\text { Microfiches, } \\
\text { microfilms }\end{array}$ & $26 \%(82)$ & $16 \%(50)$ & $29 \%(92)$ & $8 \%(24)$ & $3 \%(8)$ & $19 \%(59)$ \\
\hline $\begin{array}{l}\text { Online (Addison) } \\
\text { catalog }\end{array}$ & $1 \%(4)$ & $2 \%(6)$ & $83 \%(260)$ & $11 \%(35)$ & $2 \%(7)$ & $1 \%(3)$ \\
\hline $\begin{array}{l}\text { Online database } \\
\text { literature research }\end{array}$ & $3 \%(11)$ & $4 \%(13)$ & $77 \%(242)$ & $11 \%(35)$ & $1 \%(4)$ & $3 \%(10)$ \\
\hline Open stacks & $6 \%(19)$ & $7 \%(23)$ & $71 \%(222)$ & $5 \%(17)$ & $2 \%(5)$ & $9 \%(29)$ \\
\hline $\begin{array}{l}\text { Reference } \\
\text { counseling service } \\
\text { (reference desk/ } \\
\text { college librarians) } \\
\text { in person }\end{array}$ & $21 \%(65)$ & $20 \%(62)$ & $42 \%(132)$ & $2 \%(7)$ & $1 \%(4)$ & $15 \%(45)$ \\
\hline $\begin{array}{l}\text { Reference } \\
\text { counseling service } \\
\text { (reference desk/ } \\
\text { college librarians) } \\
\text { via online chat } \\
\text { service or email }\end{array}$ & $25 \%(80)$ & $22 \%(69)$ & $32 \%(101)$ & $3 \%(8)$ & $1 \%(4)$ & $17 \%(53)$ \\
\hline $\begin{array}{l}\text { Reference } \\
\text { workshop/ } \\
\text { orientation }\end{array}$ & $28 \%(89)$ & $13 \%(40)$ & $36 \%(115)$ & $2 \%(7)$ & $1 \%(2)$ & $20 \%(62)$ \\
\hline
\end{tabular}




\begin{tabular}{|c|c|c|c|c|c|c|c|c|c|c|}
\hline \multicolumn{11}{|c|}{$\begin{array}{c}\text { TABLE } 9 \\
\text { Difficulty Level of Taking Library Reference Workshop/Orientation }\end{array}$} \\
\hline & \multicolumn{2}{|c|}{$\begin{array}{c}\text { Not } \\
\text { Interested }\end{array}$} & \multicolumn{2}{|c|}{$\begin{array}{l}\text { Will Try } \\
\text { Later }\end{array}$} & \multicolumn{2}{|c|}{ Easy } & \multicolumn{2}{|c|}{$\begin{array}{l}\text { Difficult/ } \\
\text { Very } \\
\text { Difficult }\end{array}$} & \multicolumn{2}{|c|}{$\begin{array}{c}\text { N/A } \\
\text { (No } \\
\text { Comments) }\end{array}$} \\
\hline & Freq. & $\%$ & Freq. & $\%$ & Freq. & $\%$ & Freq. & $\%$ & Freq. & $\%$ \\
\hline International & 16 & $17.6 \%$ & 21 & $23.1 \%$ & 41 & $45.1 \%$ & 3 & $3.3 \%$ & 10 & $11 \%$ \\
\hline American & 73 & $32.6 \%$ & 19 & $8.5 \%$ & 74 & $33 \%$ & 6 & $2.7 \%$ & 52 & $23.2 \%$ \\
\hline \multicolumn{11}{|c|}{ Chi-square $=23.574, \mathrm{df}=4, p<0.001$} \\
\hline \multicolumn{11}{|c|}{$\begin{array}{l}\text { (The null hypothesis that there is no significant difference of interest level and difficulty } \\
\text { level of taking library reference workshop/orientation between international respondents } \\
\text { and American respondents is rejected.) }\end{array}$} \\
\hline
\end{tabular}

cent (182), and "Online database literature searches" 42 percent (132).

The statistical analysis shows that significantly more international respondents felt new to all these library services than their American peers, which indicates that a quite large academic library service gap exists between the United States and other countries (see table 7).

The difficulty levels of using these nine services were explored in follow-up questions. The authors deliberately offered the choice "Not interested" and "Will try later" for the students who haven't used the services (see table 8).

The Chi-square analyses find international respondents were more disposed to seek personal interactive help in their information-seeking process, although they didn't feel it was more difficult to use library services than
American respondents. 23.1 percent of international respondents showed interest in "reference workshop/orientation" and 17.6 percent said they were not interested, while only 8.5 percent of American respondents would like to try the service later and 32.6 percent showed no interest in it. 33 percent of the international respondents wanted to contact librarians for reference help later and 14.3 percent of the study group showed no interest, while only 14.3 percent of American respondents showed interest in the reference counseling service and 23.2 percent said they were not interested.

\section{Library instruction/orientation:}

Table 11 summarizes the difference in frequency of taking library instruction/ orientation between international respon-

\begin{tabular}{|c|c|c|c|c|c|c|c|c|c|c|}
\hline \multicolumn{11}{|c|}{$\begin{array}{c}\text { TABLE } 10 \\
\text { Difficulty Level of Using Reference Counseling Service in Person }\end{array}$} \\
\hline & \multicolumn{2}{|c|}{$\begin{array}{l}\text { Not } \\
\text { Interested }\end{array}$} & \multicolumn{2}{|c|}{$\begin{array}{l}\text { Will Try } \\
\text { Later }\end{array}$} & \multicolumn{2}{|c|}{ Easy } & \multicolumn{2}{|c|}{$\begin{array}{l}\text { Difficult/ } \\
\text { Very } \\
\text { Difficult }\end{array}$} & \multicolumn{2}{|c|}{$\begin{array}{c}\text { N/A } \\
\text { (No } \\
\text { Comments) }\end{array}$} \\
\hline & Freq. & $\%$ & Freq. & $\%$ & Freq. & $\%$ & Freq. & $\%$ & Freq. & $\%$ \\
\hline International & 13 & $14.3 \%$ & 30 & $33 \%$ & 36 & $39.5 \%$ & 4 & $4.4 \%$ & 8 & $8.8 \%$ \\
\hline American & 52 & $23.2 \%$ & 32 & $14.3 \%$ & 96 & $42.9 \%$ & 7 & $3.1 \%$ & 37 & $16.5 \%$ \\
\hline \multicolumn{11}{|c|}{ Chi-square $=17.145, \mathrm{df}=4, p<0.002$} \\
\hline \multicolumn{11}{|c|}{$\begin{array}{l}\text { (The null hypothesis that there is no significant difference of interest level and difficulty } \\
\text { level of using library reference counseling service in person between international respon- } \\
\text { dents and American respondents is rejected.) }\end{array}$} \\
\hline
\end{tabular}




\begin{tabular}{|l}
\hline \multicolumn{7}{|c|}{ TABLE 11 } \\
\hline \\
\hline \hline
\end{tabular}

dents and American respondents. More American respondents took library instruction in undergraduate studies, while in the graduate period, more international respondents attended library orientation. This result is consistent with the data in table 9, which shows more international respondents showed interest in library reference workshop/orientation. In general, more American respondents (70.5\%) have taken library instruction/orientation than international respondents $(61.5 \%)$.

Figure 7 lists the frequency of the answers to the follow-up question "what type of information sources were covered by the instruction/orientations?" There were 214 respondents answering this question who have taken library instruc- tion and there is no significant difference of instruction content existing between the international student group and American student group. This may be due to international respondents taking library instruction during their graduate studies in the United States.

\section{Library activities:}

Figure 8 shows that the top three most conducted library activities out of ten choices are "Search academic-related resources," "Study/Do research (using library materials)," and "Study/Do research (using my own materials)." The three bottom activities on the list are "Find nonclass related reading resources," "Group study/project," and "Meet friends."

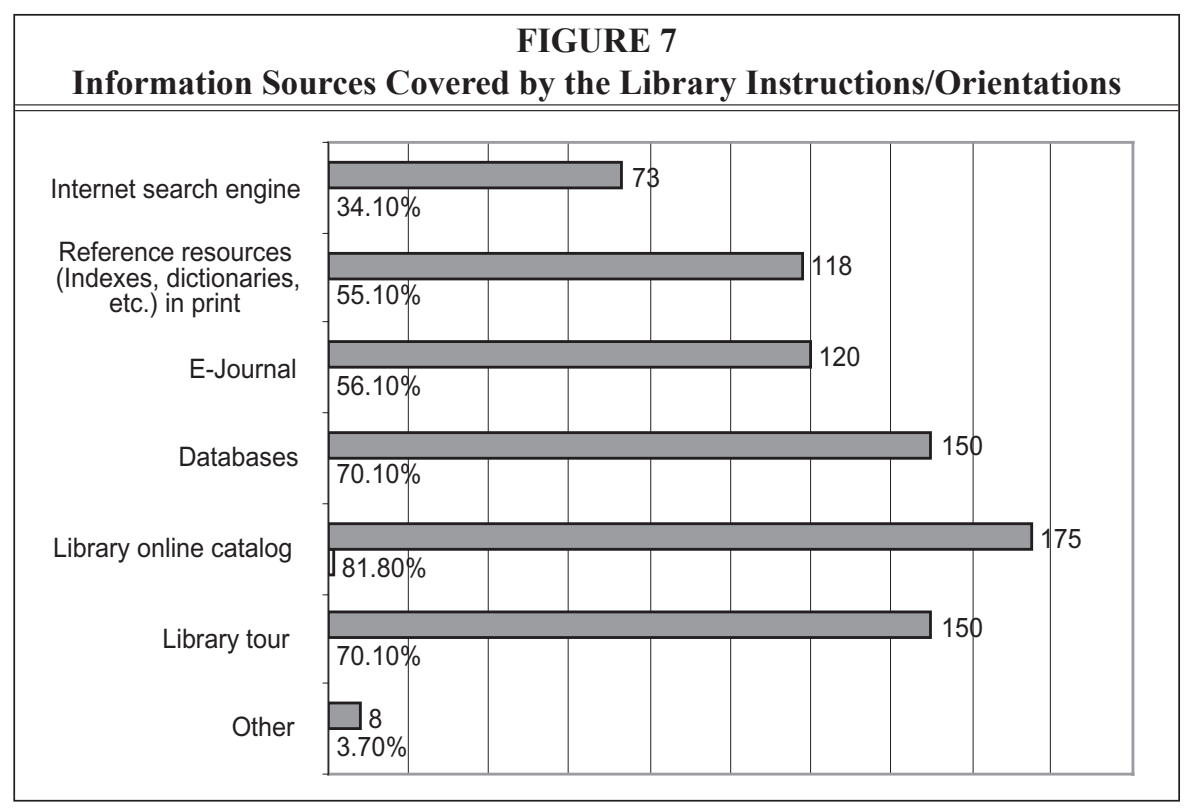




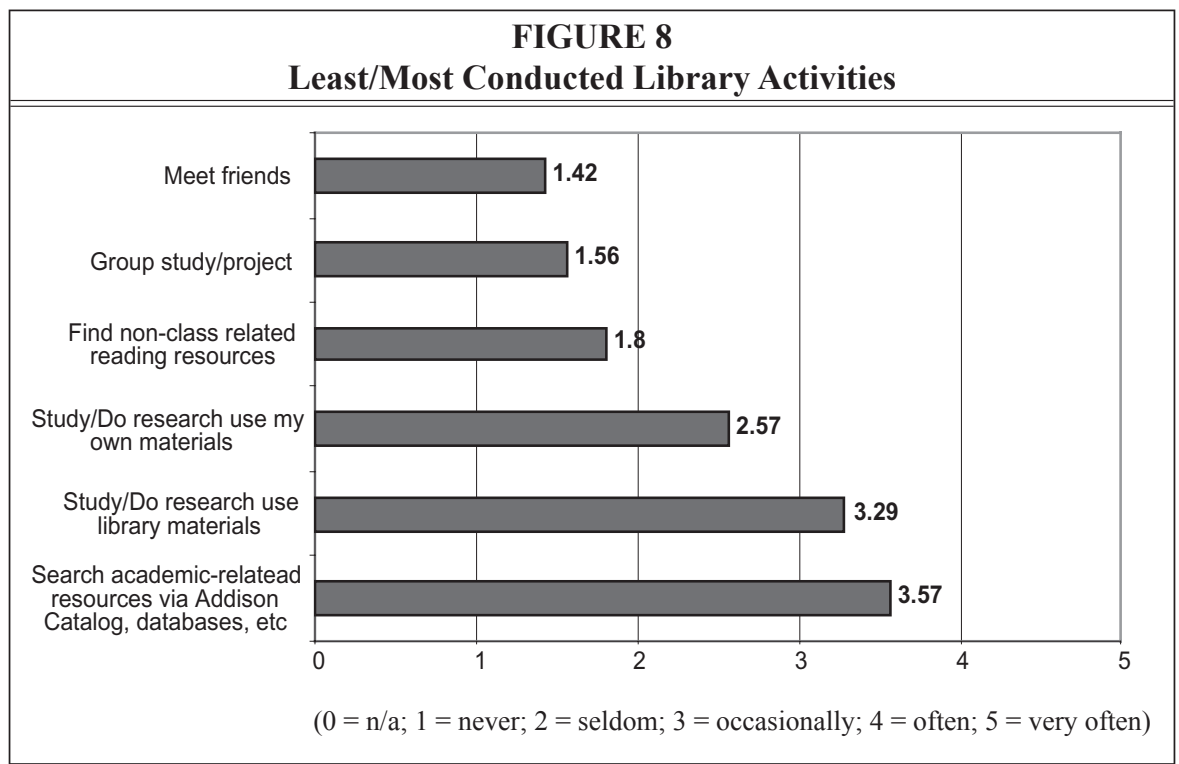

The statistical analysis shows international respondents are much more active than American respondents not only in the top three activities, but also in "Use the reserve service," "Group study/project," and "Meet friends" (see table 12 Chi-square and ANOVA). This result is consistent with the data in tables 5 and 6, which confirm that international respondents use university libraries much more often than American respondents. Some international respondents use the library not only for study and research but also as a social gathering place. This is quite different from most American respondents.

\section{Library information sources:}

Graduate students were asked to choose their favorite library information sources out of nine choices. Four choices - "Electronic resources," "Online Library Catalog," "Books," and "Print Journals" - get far more votes than other resources (see figure 9). The statistical analysis does not find any significant difference of the two study groups on this topic.

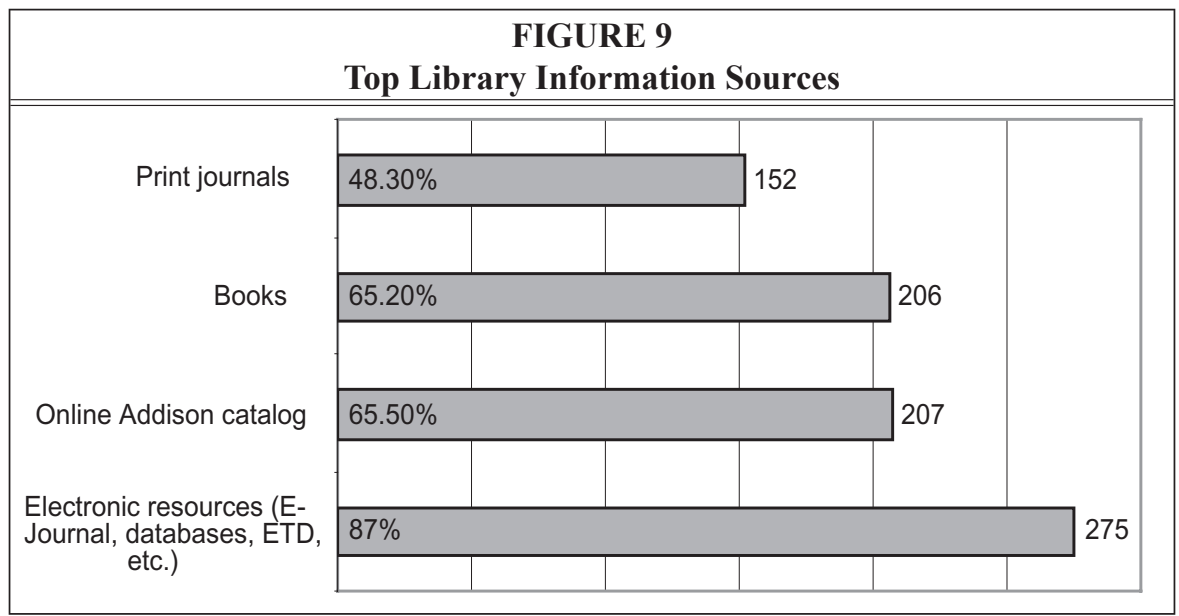




\begin{tabular}{|c|c|c|c|c|}
\hline \multicolumn{5}{|c|}{$\begin{array}{r}\text { TABLE } 12 \\
\text { Differences in Frequency of Librar }\end{array}$} \\
\hline Library Activities & $\begin{array}{c}\text { International } \\
\text { (Often/Very } \\
\text { Often) }\end{array}$ & $\begin{array}{c}\text { American } \\
\text { (Often/Very } \\
\text { Often) }\end{array}$ & $\begin{array}{l}\text { Chi- } \\
\text { square }\end{array}$ & $p$ value \\
\hline $\begin{array}{l}\text { Search academic-related } \\
\text { resources }\end{array}$ & $74.7 \%$ & $47.8 \%$ & 19.063 & $p<0.001$ \\
\hline $\begin{array}{l}\text { Study/do research (using } \\
\text { library resources) }\end{array}$ & $70.3 \%$ & $40.6 \%$ & 24.794 & $p<0.001$ \\
\hline $\begin{array}{l}\text { Study/do research (using my } \\
\text { own resources) }\end{array}$ & $48.4 \%$ & $24.6 \%$ & 22.878 & $p<0.001$ \\
\hline Use the reserve service & $22 \%$ & $8 \%$ & 17.469 & $p<0.001$ \\
\hline Group study/project & $9.9 \%$ & $2.2 \%$ & 10.078 & $p<0.006$ \\
\hline Meet friends & $8.8 \%$ & $0.9 \%$ & 27.941 & $p<0.001$ \\
\hline \multicolumn{5}{|c|}{ Differences in Frequency of Library Activities (ANOVA) } \\
\hline Library Activities & $\begin{array}{l}\text { International } \\
\text { (Freq. Mean) }\end{array}$ & $\begin{array}{c}\text { American } \\
\text { (Freq. Mean) }\end{array}$ & $\begin{array}{l}\text { ANOVA } \\
\text { F }\end{array}$ & $p$ value \\
\hline $\begin{array}{l}\text { Search academic-related } \\
\text { resources }\end{array}$ & 4.27 & 3.48 & 16.918 & $p<0.001$ \\
\hline $\begin{array}{l}\text { Study/do research (using } \\
\text { library resources) }\end{array}$ & 4.12 & 3.04 & 26.344 & $p<0.001$ \\
\hline $\begin{array}{l}\text { Study/do research (using my } \\
\text { own resources) }\end{array}$ & 3.35 & 2.30 & 24.181 & $p<0.001$ \\
\hline Use the reserve service & 2.45 & 1.72 & 18.369 & $p<0.001$ \\
\hline Group study/project & 1.64 & 1.27 & 9.376 & $p<0.002$ \\
\hline Meet friends & 1.70 & 1.13 & 29.986 & $p<0.001$ \\
\hline
\end{tabular}

\section{Reference service and interlibrary} loan:

Unlike other library services, the success of reference service and interlibrary loan depends on the cooperation and communication between patrons and librarians/staff. Many previous studies from the 1990s show these two services are the weakest link to international students.

According to the survey data, the frequency of using reference services falls between "never" and "seldom." Figure 10 shows the top three types of questions out of five choices that respondents consult with reference librarians.
The only difference in the two study groups on the topic is that international respondents consulted reference librarians for "Web search strategies" more often than American respondents (see table 13).

Figure 11 shows the reasons for the infrequent use of reference services. 80.5 percent of the respondents said that they did not need reference services. 34.9 percent never thought of asking a reference librarian, and 11 percent claimed that they did not know what a reference librarian does.

The analysis shows the number of international respondents (16.5\%) who said they did not know "what a reference 


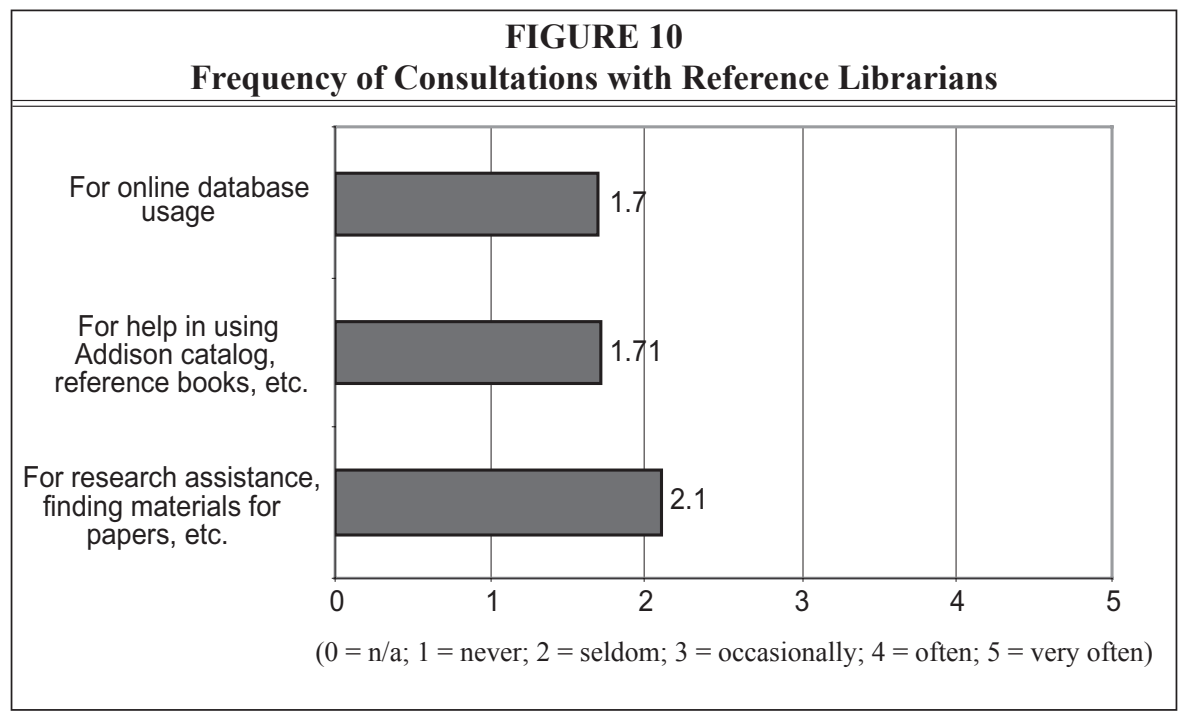

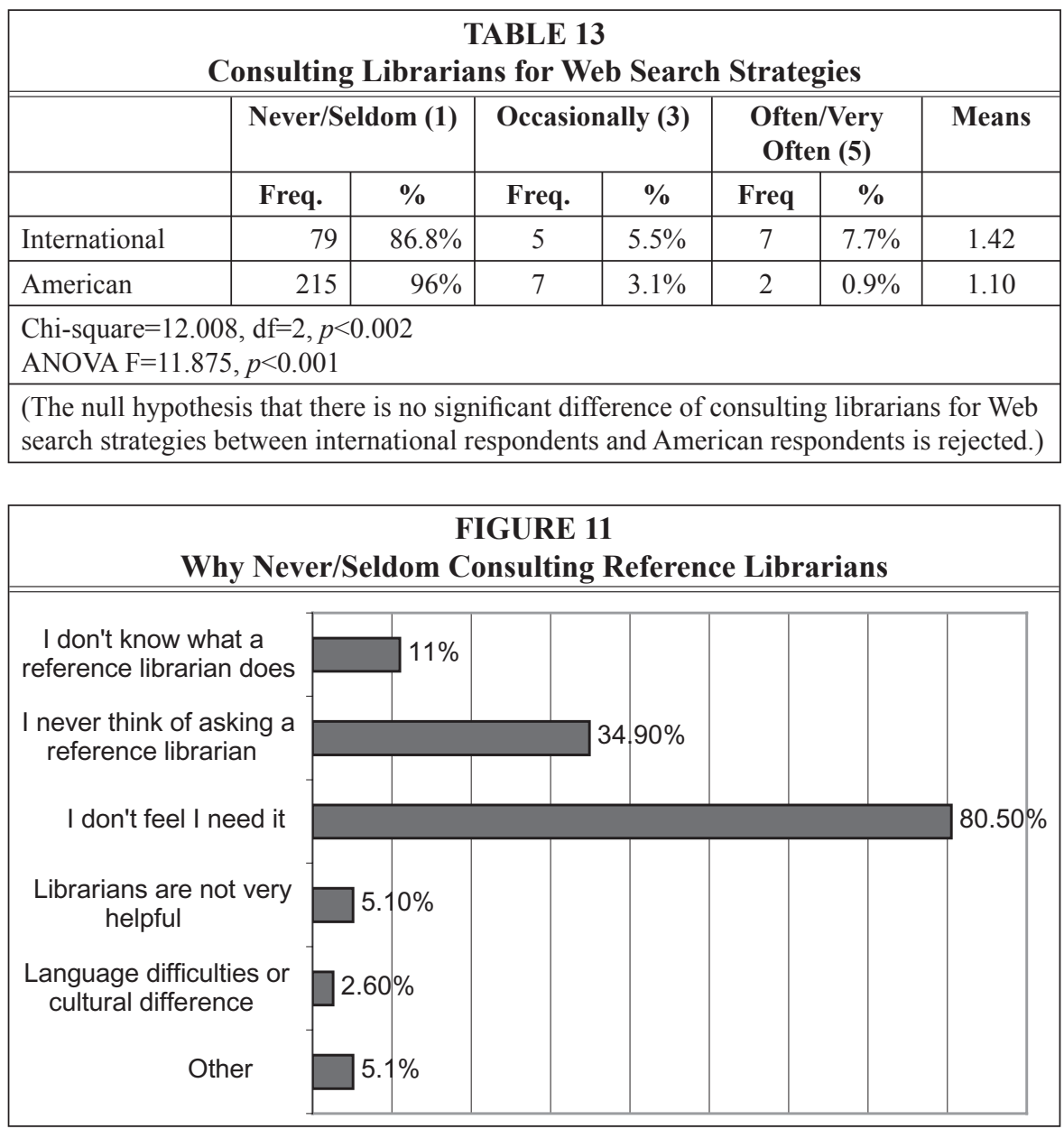




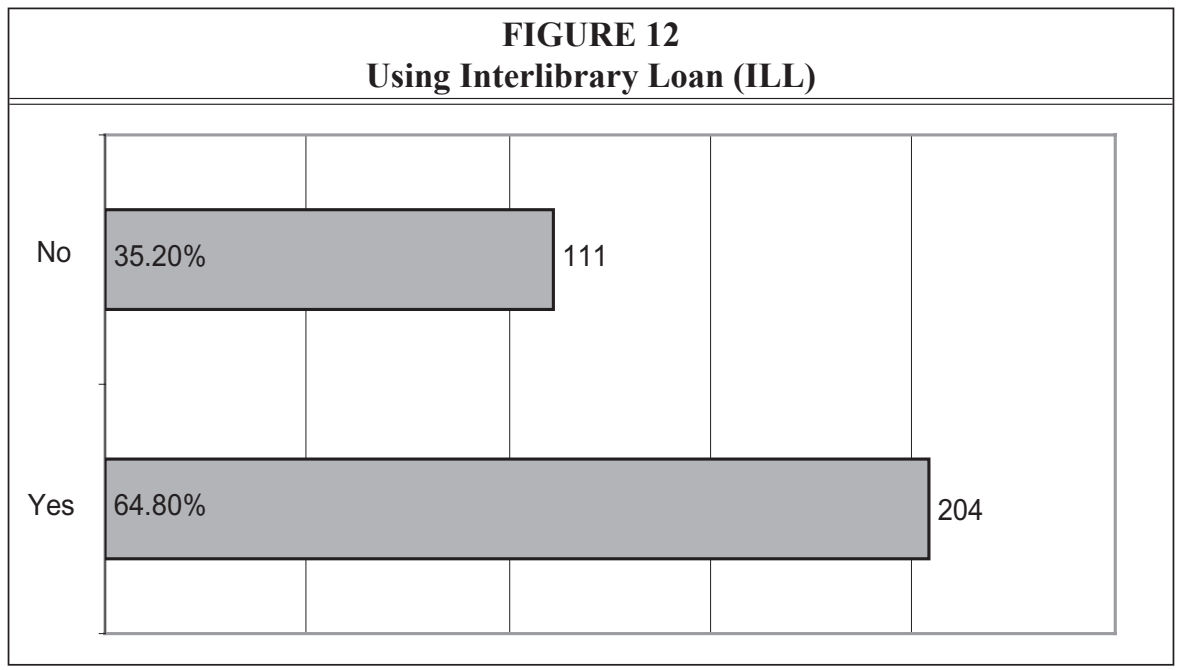

librarian does" is higher than American respondents $(6.3 \%)$ (Chi-square $=8.107$, $\mathrm{df}=1, \mathrm{p}<0.004)$. It also shows that 7.7 percent of international respondents never or seldom use reference service because of language difficulties or culture difference, while American respondents do not have this problem (Chi-square $=17.622$, $\mathrm{df}=1, \mathrm{p}<0.001$ ).

The percentage of users of interlibrary loan is higher than those who use reference services (see figure 12). The reasons for not using the service are reported in figure 13. The analysis did not show significant difference of the two study groups on either the use of the ILL service or the reasons for not using the service.

\section{Comments to university libraries}

There are four questions being asked investigating the graduate students' general evaluation of the university libraries. Figure 14 shows that the top three reasons that graduate students use libraries are "There are books/materials I want," "Convenience of location," and "Hours are convenient." Graduate studies are overwhelmingly time consuming and intellectually taxing. The result shows that convenience of time and location is

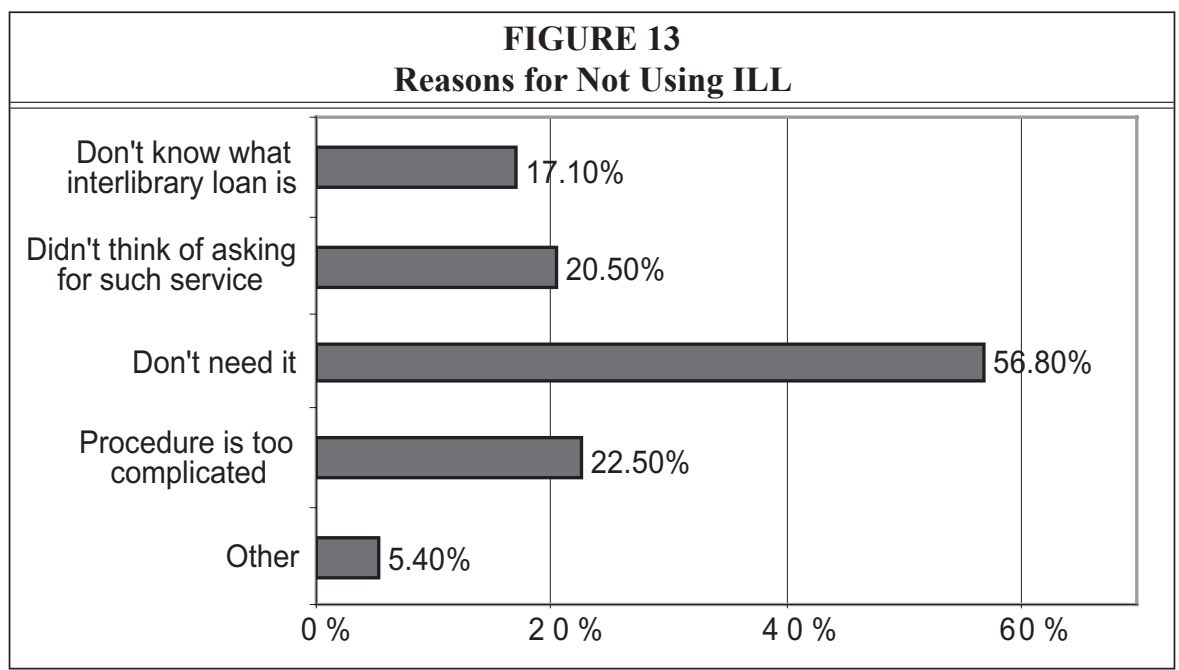




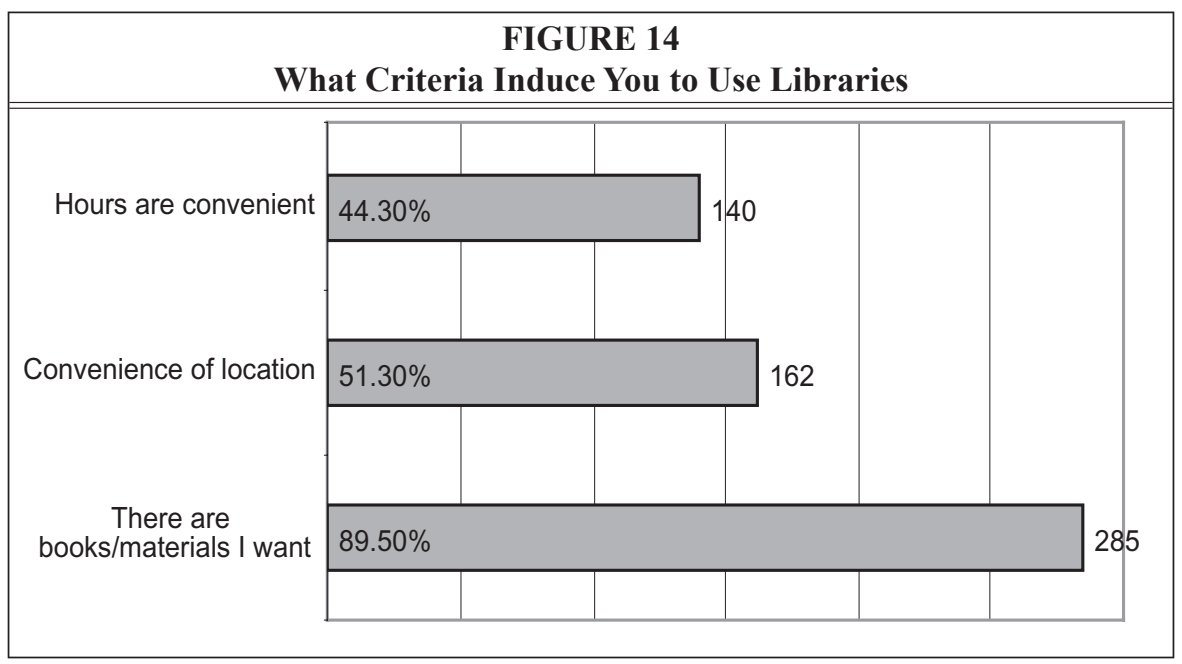

quite important to the respondents. Most graduate students are quite satisfied with the library's resources and services (see figures 15 and 16). In general, graduate students think the library is quite useful in their information seeking (see figure 17).

The statistical analysis shows that international respondents have quite similar answers to American respondents for most general evaluation questions, but international respondents value the usefulness of library in their informationseeking process higher than American respondents (see table 14).
7. English proficiency and length of stay in the United States vs. informationseeking behavior

A series of cross-tabulations and ANOVA analyses have been performed to test separately the relationships between English proficiency, length of stay in the United States and information-seeking behavior of international respondents. The analyses do not find strong connection between these factors and information-seeking behavior.

\section{Discussion}

The exponential development of digital information technology has innovatively

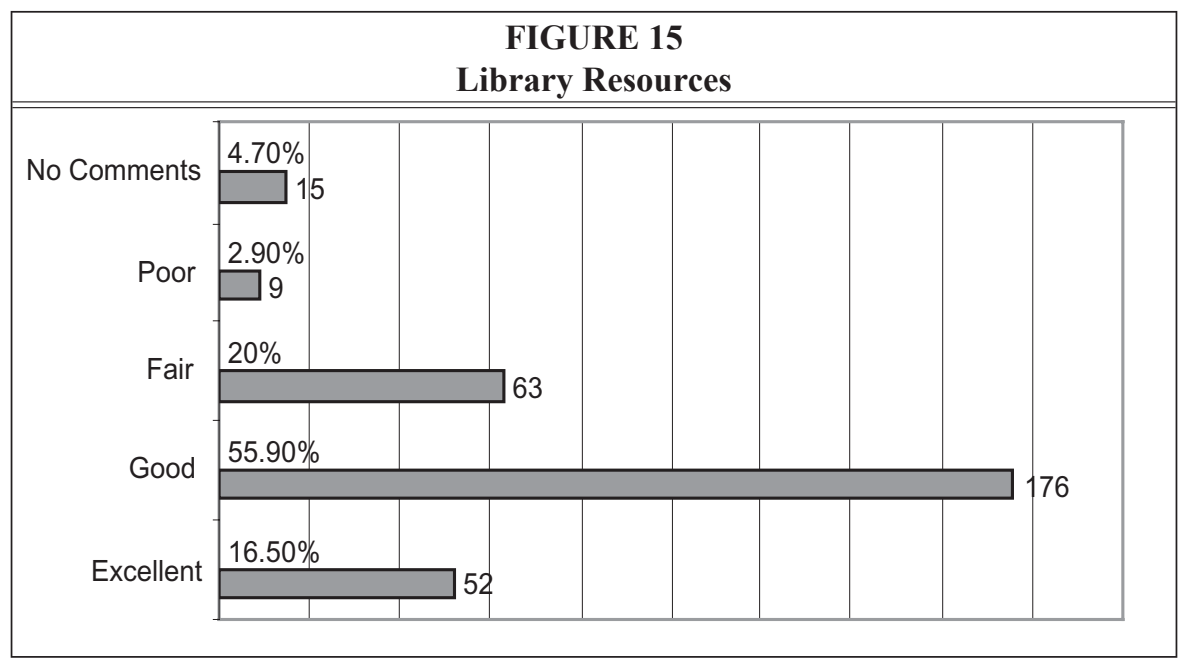




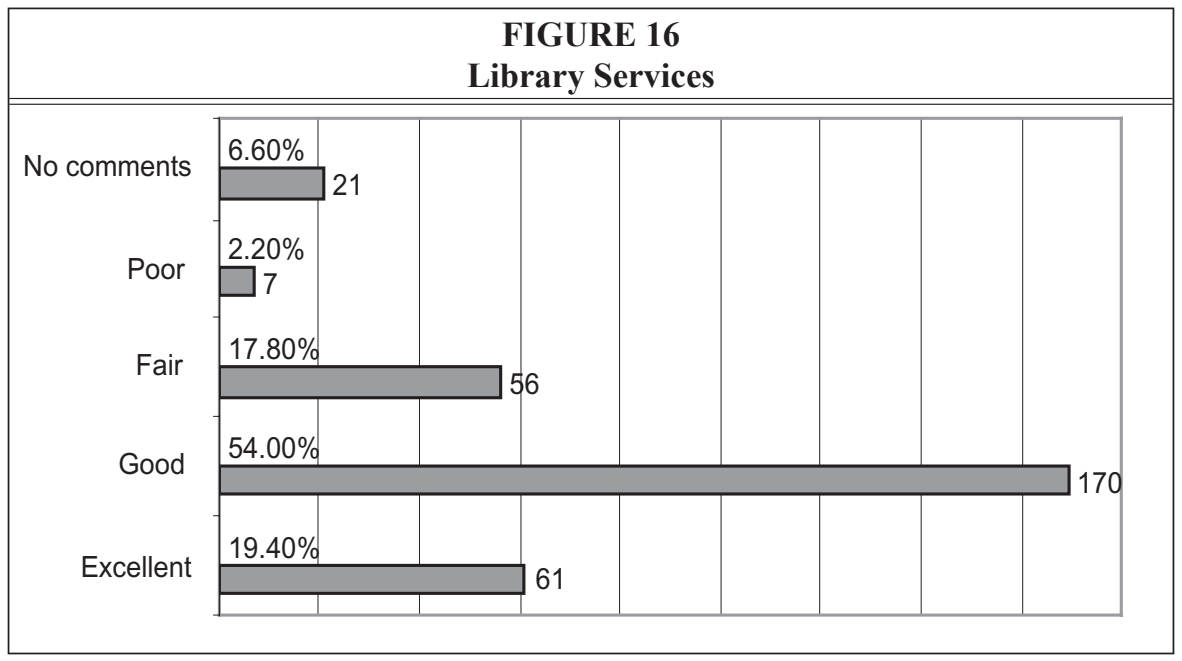

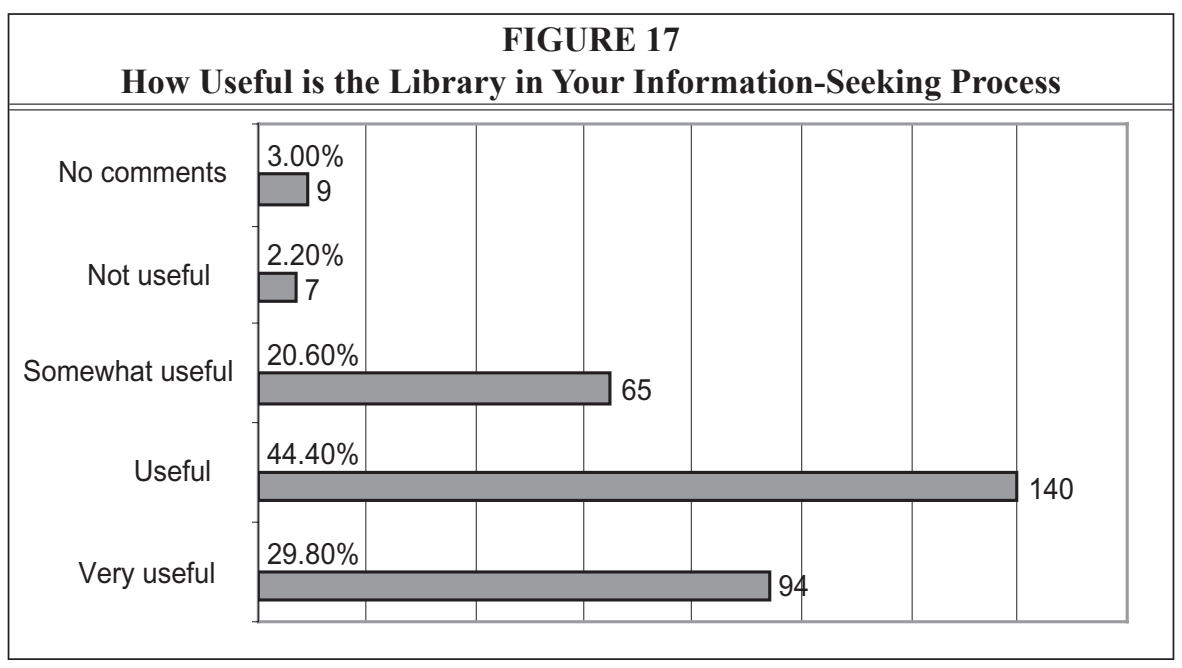

TABLE 14

How Useful is the Library in Your Information-Seeking Process

\begin{tabular}{|l|c|c|c|c|c|c|c|}
\hline \hline & \multicolumn{2}{|c|}{$\begin{array}{c}\text { N/A or Not Useful } \\
\text { (1) }\end{array}$} & \multicolumn{2}{|c|}{$\begin{array}{c}\text { Somewhat Useful } \\
\text { (3) }\end{array}$} & \multicolumn{2}{c|}{$\begin{array}{c}\text { Useful/Very Useful } \\
\text { (5) }\end{array}$} & Means \\
\hline & Freq. & $\mathbf{\%}$ & Freq. & $\mathbf{\%}$ & Freq & $\mathbf{. \%}$ & \\
\hline International & 3 & $3.3 \%$ & 10 & $11.0 \%$ & 78 & $85.7 \%$ & 4.65 \\
\hline American & 13 & $5.8 \%$ & 55 & $24.6 \%$ & 156 & $69.6 \%$ & 4.28 \\
\hline $\begin{array}{l}\text { Chi-square }=8.821, \mathrm{df}=2, p<0.012 \\
\text { ANOVA F=7.215, } p<0.008\end{array}$ \\
$\begin{array}{l}\text { (The null hypothesis that international respondents and American respondents equally value the } \\
\text { usefulness of the library in the information seeking process is rejected.) }\end{array}$ \\
\hline
\end{tabular}


and globally changed the philosophy and style of teaching, learning, and researching in academia. Being more flexible and easier to access, online information resources and searching tools are becoming the favorite choice of graduate students. During the general information-seeking process, searching the Internet and exploring library electronic resources are the top two starting methods. Web search engines are the most often used retrieval tools for both groups. Library electronic resources are preferred to other information sources and all graduate students value accessibility and convenience of access as the most important factors when seeking information resources. Despite these similarities, the study finds more international graduate students than American students find information in library books and the library online catalog plays a more important role in international students' information seeking.

The results of this study demonstrate that international students use libraries much more actively and often than American students during their graduate studies. Although American academic library services are quite new to them, they don't think those services are difficult to use. They show stronger interest than American students in reference instruction/orientation/workshops and reference counseling service in person. Language difficulties and culture differences are still obstacles for some international graduate students, but those obstacles are much less severe than they were in previous studies. The research shows that many international graduate students are quite confident about their English proficiency. With diminished communication problems, a lack of knowledge of reference services is the first encumbrance standing between international users and academic librarians.

The study also shows some distinctive characteristics of the studying style of international graduate students. Compared with American students, more international students like to do group study/ discussion in libraries. Some of them prefer searching information in online discussion forums, while few American graduate students say they do so.

Some differences in library services are found between American academic libraries and those in other countries. It seems academic libraries in the United States emphasize library education in undergraduate period more than libraries in other countries. There is still a large service gap existing between American academic libraries and university libraries in other countries. Many library services and resources in the United States are new to international graduate students who finished their undergraduate programs in their home countries. This could explain the differences in initiation methods in information seeking between American and international students. Being unfamiliar with library electronic resources, international students tend to search the Internet first, while American graduate students start from library electronic resources.

\section{Conclusion}

The multicultural character of today's collegiate population in the United States presents a challenge to academic librarians. It is important for university libraries to examine the characteristics of its user population and to develop and implement appropriate and effective services for relevant user groups. The analysis presented here describes certain characteristics of the international graduate population vs. their American peers at a large research institution.

Results of this study demonstrate that the impact of language/culture communication barriers and technology barriers on the international students' access to libraries has decreased. International graduate students are using various online searching tools and resources as often as their American counterparts. Although they are not familiar with many academic library services, they are not afraid to use them. Feelings of shame and embar- 
rassment when asking for help at the reference desk have been replaced with interest in contacting librarians and taking library instruction/workshops.

The research shows academic libraries are essential to the information seeking of international graduate students. However, these students do not have enough education about library services. Though most international graduates do not find library services difficult to use, this does not mean they are using them correctly. Basic library programs for undergraduate students, which concentrate on the introduction of various library services, could be set up for international graduate students to help them to become more familiar with university libraries and make full use of various services. Some online discussion forums and group workshops could be set up to attract more international graduate students. Since English proficiency level does not appear to be a barrier to successful library use, multilingual instructions may not be necessary in most cases. Having been familiar with many digital information technologies, international graduate students have little technical problem in using automated library systems and digital resources. They may need some instruction on higher level information competence skills, such as defining research problems precisely, formulating effective search strategies, organizing and assessing resources appropriate to academic research.

An important consideration learned through the process of distributing this survey is the close relationship between graduate students and their departments. Distribution help from the graduate program department heads has effectively promoted the response rate. Compared with American graduate students, the bond between international students and their departments is much tighter. Librarians can benefit from keeping the importance of this relationship in mind in future planning. Having been integrated into the instructional and research fabric of different academic units, university libraries could take this advantage and increase the cooperation with other academic departments. Some library marketing strategies may have better effect through cultivating interdepartmental cooperation.

Cultural diversity in the academy brings university libraries unique benefits as well as challenges. Instead of being steady, those challenges are ever-changing and intricate. There is no easy and fixed method to handle them. Continuing to study the international user group, learning their needs, and tracking their performance could be the first step on the right path. It is valuable for academic libraries to have a more comprehensive and thorough understanding of the needs of student population so that librarians can attempt to meet those needs. The interactive study process is also beneficial to the user group studied in that the respondents are provided with an introduction to various library services and are made aware of services that may be of interest to them.

\section{Notes}

1. Institute of International Education, "Interest in International Education Exchange Remains Strong in the Aftermath of September 11th according to IIE survey" (2002). Available online at http://www.iie.org/Content/ContentGroups/Announcements/Interest_in_international_educational_exchange_remains_strong_in_the_aftermath_of_September_11th_acc.htm.

2. Open Doors, "Open Doors 2004: International Students in the U.S." (2004). Available online at http://opendoors.iienetwork.org/?p=50137.

3. Virginia Polytechnic Institute and State University, "University Enrollment Profile 2005."

4. Sara Baron and Alexia Strout-Dapaz, "Communicating with and Empowering International Students with a Library Skills Set," Reference Services Review 29, no. 4 (2001): 314-26.

5. Louise W. Greenfield, "Training Library Staff to Reach and Teach International Students," LOEX 88 (1988): 46.

6. Kwasi Sarkodie-Mensah, "In the Words of a Foreigner," Research Strategies 4 (Winter 1986): 30-31. 
7. Kwasi Sarkodie-Mensah, "Dealing with International Students in a Multicultural Era," The Journal of Academic Librarianship 18, no. 2 (Sept. 1992) 214-16.

8. Mary Beth Allen, "International Students in Academic Libraries: a User Survey," College E Research Libraries 54 (July 1993): 323-33.

9. Suzanne Irving, "Addressing the Special Needs of International Students in Interlibrary Loan: Some Considerations, " Reference Librarian 45/46 (1994): 111-17.

10. Nancy Moeckel and Jenny Presnell, "Recognizing, Understanding, and Responding: A Program Model of Library Instruction Services for International Students," Reference Librarian no. 51-52 (1995): 309-25.

11. Mengxiong Liu and Bernice Redfern, "Information-Seeking Behavior of Multicultural Students: A Case Study at San Jose State University," College \& Research Libraries 58 (July 1997): 348-54.

12. Greenfield, "Training Library Staff to Reach and Teach International Students."

13. Kwasi Sarkodie-Mensah, "Dealing with International Students in a Multicultural Era."

14. Suzanne Irving, "Addressing the Special Needs of International Students in Interlibrary Loan: Some Considerations."

15. Mengxiong Liu and Bernice Redfern, "Information-Seeking Behavior of Multicultural Students: A Case Study at San Jose State University."

16. Allen Natowitz, "International Students in U.S. Academic Libraries: Recent Concerns and Trends," Research Strategies 13 (Winter 1995): 4-16.

17. Nancy Moeckel and Jenny Presnell, "Recognizing, Understanding, and Responding: A Program Model of Library Instruction Services for International Students."

18. Ibid.

19. Kwasi Sarkodie-Mensah, "In the Words of a Foreigner."

20. Mary Beth Allen, "International Students in Academic Libraries: a User Survey."

21. Jian Q. Kuang, "A Study to Determine How International Students Utilize the Library Resources and Services of the Bowling Green State University Libraries " (master's thesis, Bowling Green State University, 1989).

22. ETS, “Tests Directory: TOEFL - Test of English as a Foreign Language" (2005). Available online at www.ets.org/redirect/tests.html.

23. ETS, "TOEFL Test and Score Data Summaries" (2005). Available online at http://www.ets. org/vgn-ext-templating/v/index.jsp?vgnextoid=20beaf5e44df4010VgnVCM10000022f95190RCR D\&vgnextchannel=d35ed898c84f4010VgnVCM10000022f95190RCRD.

24. PamelaA.Jackson, "Incoming InternationalStudents and theLibrary:aSurvey," ReferenceServices Review 33, no. 2 (Feb. 2005): 197-209. 